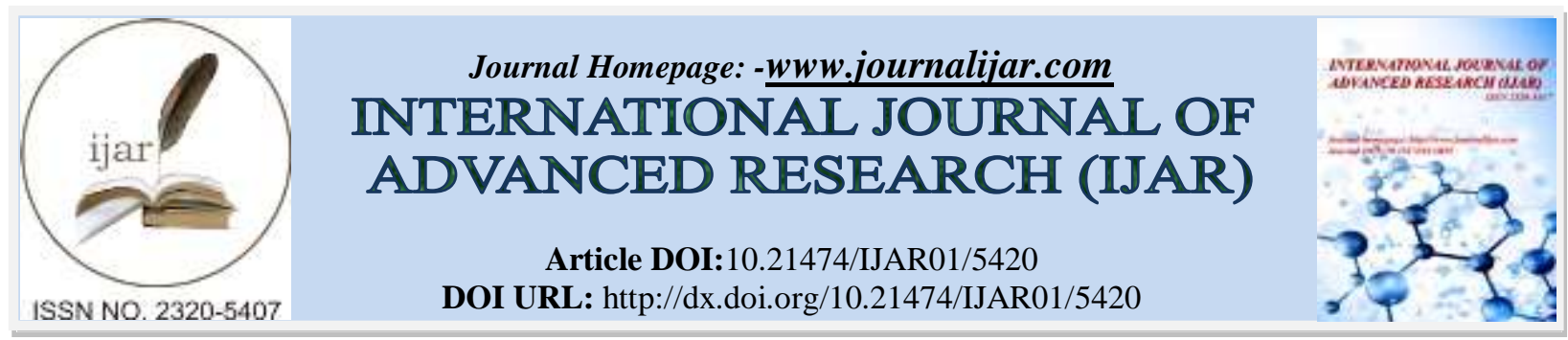

RESEARCH ARTICLE

\title{
THE DEVELOPMENT OF SCIENCE LEARNING MODULE BASED ON BRASS LOCAL WISDOM IN THE SUBJECT OF HEAT IN JUNIOR HIGH SCHOOL.
}

Subiki and Erica Febriyanti.

The Faculty of Teacher Training and Education, University of Jember,Jember, Indonesia.

\section{Manuscript Info}

Manuscript History

Received: 13 July 2017

Final Accepted: 15 August 2017

Published: September 2017

\begin{abstract}
Science learning in reality still had difficulty. Based on the result of interview with the science teacher of SMPN 2 Tapen the case that the materials used was lack of integration of material with the environment around which is less contextual and too general, so that student didnot recognize local wisdom in their around. Based on these problem, the innovation of science module development based local wisdom was needed. The research purposes were to describe validity, effectivity, and module practicality by using developing design of ADDIE. The technique of data collection werevalidation sheet, pre test, post test sheet and student response. While technique of data analysis validation used descriptive analysis quantitative, effectivity used technique test and student responsed used percentage of agreement. The result of expert validation was 4,28 while user validation was 4,54 so module was valid. Average score in pre-test was 30.8 , post-test average was 65.8 , while $\mathrm{N}$-gain average was 0.5256 the criteria was medium. The result of average student responsed was $96,05 \%$ its meant module was practical. Science module development with brass local wisdom based in the topic of heat in junior high school was effective to use as material in the topic of heat.
\end{abstract}

Copy Right, IJAR, 2017,. All rights reserved.

\section{Introduction:-}

Learning is essentially a reciprocal transactional communication process, either between teacher and student, or between student and student[5].In summary, it can be said that science is a human effort to understand the universe through observations of the right (correct) at the target, as well as using the correct procedure (true), and is described with reasoning (valid) so that resulting correct conclusions (truth). Thus, science contains three things: the process (the human effort to understand the universe), the procedure (proper observation and correct procedure), and the product (the conclusion is correct) [13].

In fact, science learning in the field is still experiencing some obstacles.Based on the interview with a science teacher of SMPN 2 Tapen, the obstacle oflearning at SMPN 2 Tapen was that the teaching materials used has shortcomings, especially in the integration of materials with the surrounding environment which is less contextual and is too general, so that students less recognize local wisdom in the area around the students. Another problem is the determination of learning materials that were relevant to local wisdom.It caused teacher's learning resource largely gained from the government publications instead of developing the creativity of teachers.

Based on this, the innovation by providing science learning materials based on local wisdom was needed.One of types of teaching material which could be developed was in the form of science modules.Modules played a role in creating innovative and creative learning.Learning using moduleswhich can be used to solve the problems was to 
implement a module that provides firsthand experience, challenging and fun for students. With the module, students become active in the learning process andalso more enthusiastic about learning [7].

Local wisdom in environmental management means managing the local potential.Developing local potential from traditional local wisdom possessed by the community.The integration of knowledge based on local wisdom into learning gives students the chance to express their thoughts, to accommodate the concept based on traditional science, enhance creativity, creating effective learning and a more conducive learning environment [4].

Effective learning is a learning that allows students to learn easily, fun, and learning objectives can be achieved according to the expectations [20].The effectiveness of teaching can be determined by giving tests since the test results can be used to evaluate various aspects of teaching [17].The effectiveness is seen to assess the quality of teaching materials have been developed, the effectiveness of the module is seen from the level of success achieved by students after the learning using modules [14].

Heat is a science material that is very familiar with human activities in daily life. With the result that in the delivery of learning, it requires a contextual linking as local wisdom.By this conception, the students not only instilled theoretical concept, but the concept application in daily life like local wisdom can also be implanted.Relevant research on local wisdom has also been done by other researchers.Previous studies measuring the results of learning, but in this study, the researcher measured the effectiveness.Based on a research conducted by Azizahwati [1], it showed that the quality of learning sets local wisdom based was developed through a series of test validity by thevalidator was categorized as feasible to use. Then after the implementation of local wisdom based learning, the learning achievement was increased. It proved that local wisdom could improve students' interest.

Based on the description of the problems the lack of integration of the material to the environment, it is necessary to develop an effective science modules and integrated into the local wisdom with problem formulation of how the validity of science learning modules based on local wisdom brass on the subject of heat, how the effectiveness of the science learning modules based on local wisdom brass on the subject of heat, how practicality in science learning modules based on local wisdom of brass on the subject of heat.The purpose of this study was to describe module validity, module effectiveness and science learning modules based on local wisdom on the subject of heat brass practicality.

\section{Methods:-}

This research was ADDIE development model that consisted of 5 development stages, analyze,design, development, implementation and evaluation[15]. According to Pohan et al [11] the ADDIE model was a traditional development process that is general in designing teaching and practice.This study was designed to obtain a product in the form of moduleslocal wisdom-based science learning brass on the subject of heat in class VII junior high. The developed science learning was printed materials in the form of module for students. The design of the study was ADDIE development model with the stages accordance to the research [2].

Science learning module that raised the local wisdom was a science learning module that raised the local wisdom around the students, namely brass and the process of making it.Modules developed in the limit on the subject of heat and will be measured the feasibility of the module to be used based on three aspects namely the validity, effectiveness and practicality.

Data collection instrument in this study using the instrument validation sheet, sheets of pre-test and post-test, and the student responses questionnaire.Data acquisition techniques are validation, test, questionnaire, and documentation. The data analysis technique to measure the validity of the module was done by using descriptive analysis of quantitative and qualitative.The formula used for analysis validation is as follows.

$$
V_{a}=\frac{\sum_{i=1}^{n} A_{i}}{n}
$$

$\mathrm{V}_{\mathrm{a}}$ : the average value of the total for all aspects

$\mathrm{A}_{\mathrm{i}}$ : rata-rata nilaiaspekke- $I$

$\mathrm{n}$ :number of aspects [6] 
Data analysis techniques to determine the effectiveness of the module was done by using descriptive analysis of quantitative and qualitative, using pre-test and post-test.Then $\mathrm{N}$-gain test technique was done according the research of Wasi'atuset al [19] the results showed the effectiveness of 0.68 meant including in the criteria of medium, the module that students used was effective. The results of the pre-testand post testwere then calculated the value of NgainBased on the following formula.

$$
\mathrm{g}=\frac{\mathrm{Xm}-\mathrm{Xn}}{100-\mathrm{Xn}}
$$

By:-

$\mathrm{g}=$ The value gain

$\mathrm{Xm} \quad=$ The value post test

$\mathrm{Xn} \quad=$ The valuepre test [12]

The data analysis technique to measure the response of students to determine the practicality of modulewas done by using percentage of agreement.The formula used to calculate the percentage of each aspect according to the formula in the equation:

$$
\text { Percentage of agreement }=\frac{R}{M} \times 100 \%
$$

Keterangan:

$\mathrm{R}=$ = Proportion of the number of students whoChoose to agree

$\mathrm{SM} \quad=$ Number of students

\section{Results and Discussion:-}

The first stage was analysis. This phase was used to collect a variety of information as planning material [22].Based on the interview with one of the science teachers at SMPN 2 Tapen, the data include were: (1) students of SMPN 2 Tapen mostly live in the area around brass craftsman, (2) science learning process in SMPN 2 Tapen was not associated to expertises during the making of brass with learning, (3) there had been local content in the school curriculum, but had not been associated with local wisdom around the school, and (4) science books used were published by the Government and commercial publishers

The second stage was design. The selected form in designing module was module presented by linking contents of science, environment, technology and society with the theme of local wisdom that was brass.According to the research of Triani et al.[16] the module was designed by using 2010 microsoft office publisher.

The third stage was the development of a module structure that includes: (1) front page, (2) title page,(3) preliminary, (4) usage guidance,(5) content list,(6) introduction,(7) content standards, (8) a concept map, (9) local wisdom,(10) learning activities,(11) learning materials,(12) exercise, formative test (13) assessments signs, and (14) answer key. 


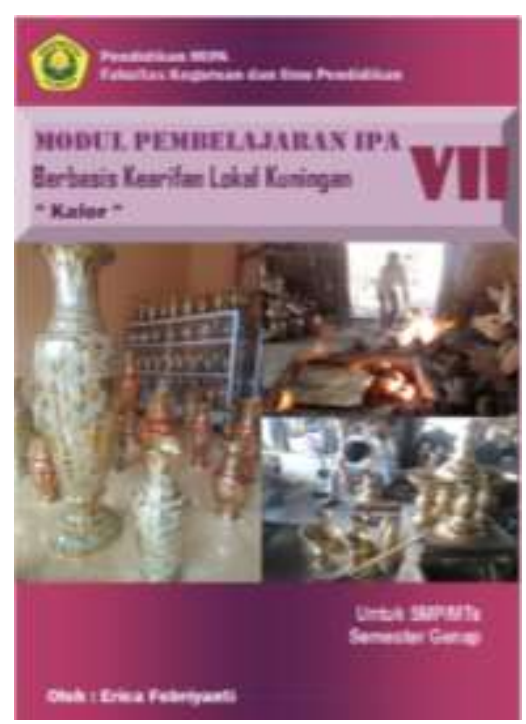

Figure 1.The front page appearance.

The next stage was validation. Expert validation consisted of two lecturers of Physics Education Program University of Jember and user validation by two teachers of SMPN 2 Tapen.Furthermore, from two stages of validation, the calculation of the test results average of expert validation and user validation were done.Then obtained the validation resultsas follows

Table 1:-Data from expert and user validation.

\begin{tabular}{|c|c|c|c|c|}
\hline Field & Average field & Expert validation & Average field & User validation \\
\hline $\begin{array}{l}\text { Feasibility of } \\
\text { Content }\end{array}$ & 4,07 & \multirow{4}{*}{$\begin{array}{c}4,28 \\
\text { Valid }\end{array}$} & 4,12 & \multirow{4}{*}{$\begin{array}{c}4,54 \\
\text { Valid }\end{array}$} \\
\hline $\begin{array}{l}\text { Feasibility of } \\
\text { Presentation }\end{array}$ & 4,32 & & 4,88 & \\
\hline $\begin{array}{l}\text { Channel } \\
\text { Feasibility }\end{array}$ & 4,59 & & 4,67 & \\
\hline $\begin{array}{l}\text { Language } \\
\text { Feasibility }\end{array}$ & 4,17 & & 4,54 & \\
\hline
\end{tabular}

Based Table 1, the average of quantitative data from two validators expert assessment of the science learning modules based on local wisdom brass on the subject in junior high calorific material was derived from the average of 4.28 for four areas, namely, appropriateness of content, presentation feasibility, graphics feasibility and language feasibility according to the study of Wahyuni and Durinta [18].In the field of validation values obtained contents feasibility 4.07 due to the material presented was incomplete and consistencyin using notations and symbols.

In presentation feasibility field validation values obtained at 4.32 , while graph feasibility field validation values obtained by 4.59.Language feasibility field validation value amounted to 4.17 since the phrases used in the module were less effective. While the average of user validator was 4.54 obtained from average as well as on the validation expert.In the content feasibility field obtained an average validation value of 4.12 because the material presented was less extensive. At the presentation feasibility field values obtained validation of 4.88 .

Graph feasibility field obtained a value of 4.67 and on the feasibility of acquired language validation valued by 4.50 . The value indicated that the science learning module based on local wisdom on the subject of heat in junior high school fulfilled valid criteria and can be used with the revision, which was in line with the research of Hasanah [3] modules disaster mitigation based on local potential in science lessons in junior high school was categorized as valid with an average value of 4.15 total $\mathrm{Va}$ at intervals of $4 \leq \mathrm{Va}<5$ included in valid category [6].

The fourth stage was the implementation phase.In this stage module tested in class VII A with the number of students by 30 voted to determine the effectiveness and practicality.The data of experiment result on local wisdom 
science learning module on heat subject in SMP was obtained by executing development test at SMP Negeri 2 Tapen, Bondowoso.The subjects were 30 students of class VII A. Development test was conducted in 6 meetings.

Data of development test result which was gained in this research was data of student learning of cognitive domain and student response.Data of student learning achievement in cognitive domain obtained from the pre-test conducted at the beginning of the meeting and post-test at the last meeting.The average score of the class on the activities of the pre-test was at 30.8, while the average score of post-test 65.8 with a post test score difference from the pre-test and post-testat 35. According to the study conducted by Muzari et al. [8], this module obtained by using $N$-gain test.Score of test results of $N$-gainshown in Table 2 below:

Table 2:-The test results of $N$-gain,

\begin{tabular}{|c|c|c|c|}
\hline Component & Pre test & Post test & N-gain \\
\hline Average & 30,8 & 65,8 & \\
& 49 & 96 & 0,5256 \\
Highest score & 49 & 25 & (Moderate) \\
\hline The lowest score & 12 & & \\
\hline
\end{tabular}

Based on Table 2 obtained a value of 0.5256 indicated that the enhancement of students' learning achievement before and after using the modules currently on the medium criteria, that according to research by Putra and Sudarti [12] the enhancement of students' critical thinking skills in the use of real-life video evaluation using e-learning system in the category of medium with the acquisition of $\mathrm{N}$-gain of 0.48.Based on the acquisition of this study, the learning module of science based on local wisdom of brass on the subject of heat in SMP was effective in improving students' learning outcomes in the cognitive domain.

Science modules based on local wisdom could not yet improve learning outcomes fully as obtained $\mathrm{N}$-gain of 0.5256 was not greater than $0.7 \mathrm{~N}$-gain in the high category. It caused by a shortage in applying science learning modules based on local wisdom of brass to students, namely science learning modules based on local wisdom of brass was presented colorless. However there were significant differences on the cognitive learning outcomes of students between before and after using science learning modules based on local wisdom of brass seen from the average in pre-test and post-test at 30.8 by 65, 8 according to the research by Ni Putu and Putu [9] there was a significant difference between before and after using the module with the pre test and post-test of 67.40 at 86.70 .

Student response data to the science learning modules based on local wisdom on the subject of heat in junior high school obtained from the student responses questionnaire sheet, by providing responses to the student questionnaire sheet using Guttman scale.Student response data on each aspect can be seen in Table 3 below:

Table 3:- Student response questionnaire data

\begin{tabular}{|c|l|c|c|}
\hline No & \multicolumn{1}{|c|}{ Aspect } & Percentage of agreement & Category \\
\hline 1 & Content & $94,00 \%$ & Very Practical \\
\hline 2 & $\begin{array}{l}\text { Feasibility of } \\
\text { Presentation }\end{array}$ & $96,67 \%$ & Very Practical \\
\hline 3. & Achievement of Goals & $97,50 \%$ & Very Practical \\
\hline & Rate & $96,05 \%$ & Very Practical \\
\hline
\end{tabular}

Based on Table 3, it was known that the percentage of agreement on all the aspects were in the category of very practical.Obtained on the content aspect of egreement percentage of $94.00 \%$ as the category of very practical, on the feasibility aspect of the content acquired $96.67 \%$ percentage of agreement was very practical category and on aspects of goal achievement percentage of agreement of $96.05 \%$ with a very practical category.In accordance with a research by Nailiyah [10] students' positive response as much as $95.6 \%$ in all aspects and on this research as well, the students respond positively to the science learning modules based on local wisdom and practicality level was 96, $05 \%$.So it could be stated that the students were interested in the modules developed in accordance with the research by Wulandari [21] stated that students were interested in the modules developed that was teaching materials developed namely pocketbook Sahabat IPA seen from the average of positive responses of students by $88,67 \%$. The fifth stage was the evaluation, the evaluation stage was only done through formative evaluation only. 


\section{Conclusion:-}

Based on the analytical results obtained, it could be concluded as follows: (1) science learning modules based on local wisdom on the subject of heat in SMP Negeri 2 Tapenhad valid criteria and was fit to use as learning resource in the material of heat, (2) science learning modules based on local wisdom on the subject of heat in SMP Negeri 2 Tapen was effective and feasible to use as learning resource in the material of heat, and (3) science learning modules based on local wisdom on the subject of heat was categorized as very practical and was fit to use as Teaching materials on caloric materials in junior high.

\section{References:-}

1. Azizahwati, Z. Maaruf, R.M. Yassin, dan E. Yuliani. 2015. PengembanganModulPembelajaranFisik SMA BerbasisKearifanLokalUntukMeningkatkanHasilBelajarSiswa. ProsidingPertemuanIlmiah. 25 April 2015: 08530823

2. Ghaliyah. S, F. Bakri, danSiswoyo. 2015. PengembanganModulElektronikBerbasis Model Learning Cycle 7E PadaPokokBahasanFluidaDinamikUntukSiswa SMA Kelas XI. Prosiding Seminar NasionalFisika. Oktober 2015 : 2339-0654

3. Hasanah, I. 2016. PengembanganModulMitigasiBencanaBerbasisPotensiLokal yang TerintegarsidalamPelajaran IPA di SMP. JurnalPendidikanFisika. 5(3): 226-234

4. Hatimah, I. 2006. PengelolaanPembelajaranBerbasisPotensiLokal di PKBM. MimbarPendidikan, 25 (1):40-45

5. Hermawan, A.H. 2008. PengembanganKurikulumdanPembelajaran. Jakarta: Universitas Terbuka

6. Hobri. 2010. MetodologiPenelitianPengembangan. Jember: Pena Salsabila

7. Mashinta, A. 2015. PengembanganModul IPA terpadu SMP/MTs dengan Model Problem Based Learning Tema Air Sehat. JurnalInkuiri. 4(1): 73-81

8. Muzari, I, Ashadi, dan B.A Prayitno. 2016. PengembanganModul IPA TerpaduBerbasis SETS PadaTemaMakananSehatdanTubuhkuUntukMeningkatkanHasilBelajar. JurnalInkuiri. 5(1): 21-27.

9. Ni Putu, D.E dan D. Putu. 2016. PengembanganModul IPA BerorientasiPendidikanKarakterPelajaran IPA Kelas VII Semester Genap di SMPN 1 Negara. JurnalEdutechUniversitasPendidikanGanesha. 5(2): 1-11

10. [10] Nailiyah, M.R. $2016 . \quad$ PengembanganModul IPA TematikBerbasisEtnoSainsKabupatenJemberPadaTemaBudidayaTanamanTembakau Di SMP. JurnalPendidikanFisika. 5(3): 261-269.

11. Pohan. J.E, Atmazaki, danAgustina. 2014. PengembanganModulBerbasisPendekatanKontekstualPadaMenulisResensi di Kelas IX SMP 7 Padang Bolak. JurnalBahasa, SastradanPembelajaran. 2(2): 1-11

12. Putra, P.D.A, danSudarti. 2015. Real Life Video Evaluation denganSistem ELearning untukMeningkatkanKeterampilanBerpikirKritisMahasiswa. JurnalKependidikan. 45(1): 76-89

13. Suharnanik, Lilik. 2014. MeningkatkanHasilBelajarSiswaPada Mata Pelajaran IPA (PokokBahasanSistem Tata Surya) MelaluiPendekatanKontekstualPadaSiswaKelas VI C SDN TanggulWetan 02 Jember. JurnalPancaran. 3(2): 175-184.

14. Suryani, D.I, T. Suheri, dan A. R, Ibrahim. 2014. PengembanganModul Kimia ReaksiReduksiOksidasikelas X SMA. JurnalPendidikan Kimia. 1(1): 18-28

15. [15] Tegeh, I. M, I. N. Jampel, dan K. Pudjawan. 2014. Model PenelitianPengembangan. Singaraja: GrahaIlmu

16. Triani, P. D, Nasarudin, dan M. Rusdi. 2017. PengembanganModulBerbasisPemecahanMasalahPadaMateriAsamBasa di SMAN 5 Kota Jambi untukMembangunKeterampilanMetakognisiSiswa. JurnalPendidikan Kimia. 9(1): $286-292$.

17. Trianto. 2010. Model PembelajaranTerpadu: Konsep, Strategi, danImplementasinyadalamKurikulum Tingkat SatuanPendidikan. Jakarta: PT.BumiAksara

18. Wahyuni, H.I, danDurinta. 2017. PengembanganModulPembelajaranBerbasisKurikulum 2013 KompetensiDasarMengemukakanDaftarUrutKepangkatandanMengemukakanPeraturanCuti. JurnalPendidikanEkonomiManajemendanKeuangan. 1(1): 54-68

19. Wasi'atus, S, E. Suarsini, danIbrohim. 2016. PengembanganModulBioteknologiLingkunganBerbasisPenelitian Mata KuliahBioteknologiuntukMahasiswa S1 UniversitasNegeri Malang. JurnalPendidikan. 1(9): 1781-1786, September 2016

20. Warsita, B. 2008. TeknologiPembelajarandanLandasandanAplikasinya. Jakarta: RinekaCipta

21. Wulandari, T. 2016. Pengembangan Pocketbook Sahabat IPA PadaMateriIndraPendengarandansistem Sonar di SMP. JurnalPembelajaranFisika. 5(3): 227-284.

22. Zahro, U.L danVina. 2017. PengembanganLembarKerjaSiswa (LKS) FidikaDenganMenggunakanStrategi Relating, Experiencing, Appliying, Cooperating, Transferring (REACT) BerbasisKarakterPadaPokokBahanHukum Newton. JurnalWahanaPendidikanFisika. 2(1): 63-68 